\title{
The Impact of Corporate Social Network on Innovation: A Mediation Analysis of Agency Costs and Financial Constraints
}

\author{
Gejian Feng*, Jianqiong Wang \\ School of Economics and Management, Southwest Jiaotong University, Chengdu, China \\ Email: ^fenggejian@my.swjtu.edu.cn
}

How to cite this paper: Feng, G.J. and Wang, J.Q. (2020) The Impact of Corporate Social Network on Innovation: A Mediation Analysis of Agency Costs and Financial Constraints. Journal of Mathematical Finance, 10, 536-568.

https://doi.org/10.4236/jmf.2020.104033

Received: September 12, 2020

Accepted: October 18, 2020

Published: October 21, 2020

Copyright $\odot 2020$ by author(s) and Scientific Research Publishing Inc. This work is licensed under the Creative Commons Attribution International License (CC BY 4.0).

http://creativecommons.org/licenses/by/4.0/

\begin{abstract}
This paper examines the impacts of corporate social network on innovation activities (both R\&D inputs and patent outputs) and explores the potential influence path of social networks driving corporate innovation. Using Chinese share markets' listed companies in the period from 2009 to 2016 as the sample, we establish a new type of social network based on the connections of the core management team (including directors, supervisors and executives) and find that a corporate social network based on the core management team has a positive causal effect on enhancing R\&D investments and patent performance. Empirical results are robust after controlling for endogeneity and the causal relationship between social networks and corporate innovation is robustly monotonic. We perform a mediation analysis following the bootstrapping procedures, and find that alleviating financial constraints plays a mediating role in the process of a social network of this new type improving corporate innovation, while mitigating agency conflicts does not. Our conclusions demonstrate that, in the promotion of corporate innovation by the corporate social network, financial constraints have a more profound impact than agency costs.
\end{abstract}

\section{Keywords}

Corporate Innovation, Social Network, R\&D Investment, Patent

Performance, Agency Costs, Financial Constraints

\section{Introduction}

Corporate innovation ability is an important factor affecting a firm's value and economic performance. An active innovation strategy can provide a continuous driving force for the sustainable development of the company. Under the back- 
ground of networking of corporate social relations, the influence of corporate innovation activities has broken through simple stakeholder boundaries. Corporate innovation-related decision-making and innovation behavior will spread widely throughout the social network. The social network theory indicates that a company's decision-making behavior is not only constrained by its own corporate characteristics but also affected by its social network relationships. Our survey finds that companies with rich social connections usually invest more money in research and development (R\&D) and exhibit better patent output performance. Considering the example of Chinese listed companies in 2016, the average $R \& D$ input intensity (defined as the ratio of $R \& D$ expenditures to operating income) was $3.73 \%$. Each company applied for 28.50 new patents, on average, of which 15.19 patents were successfully granted. At the end of 2016, each company held an average of 116.02 valid patents. Among companies with abundant social network connections, TIANMA (Stock ID: 000050) had 25 core management members (including directors, supervisors and executives) serving in other listed companies at the same time. In 2016, TIANMA's R\&D investment intensity was 10.04\%; the company applied for 1017 new patents (311 were granted) and held 697 valid patents. TRUKING (Stock ID: 300358) had 22 core managers working in other companies, and its $\mathrm{R} \& \mathrm{D}$ investment intensity, the number of new patent applications and the number of valid patents were $10.35 \%, 141$ and 1104, respectively. A total of 118 of TRUKING's new patents had been granted. In addition to TIANMA and TRUKING, there are many other similar examples. The more social network connections a company has, the better the company's R\&D investment and patent performance. Therefore, we infer that there may be some internal relationship between the corporate social network based on the core management team and innovation activities (both R\&D inputs and patent outputs), which is the core of the research questions of this paper.

Because R\&D decisions involve information asymmetry between the firm's owners and its management team, R\&D activities face significant adverse selection and moral hazard problems. Managers' adverse selection and moral hazard would cause serious agency conflicts [1] [2] [3]. Agency problems make managers tend to abandon $\mathrm{R} \& \mathrm{D}$ projects with uncertain and long-term payoffs, and managers fear the costs associated with $\mathrm{R} \& \mathrm{D}$ and favor relatively safe projects with short-term payoffs. Additionally, information asymmetry also occurs between external providers of funds and internal managers. It is difficult for a firm with a high degree of information asymmetry to finance R\&D from external sources [3] [4] [5]. Information asymmetry limits firms' access to external finance and leads to severe financial constraints in R\&D activities. We argue that information asymmetry is the primary cause of agency conflicts and financial constraints. Existing studies show that social networks can boost the sharing of information and reduce information asymmetry within a network. Freeman (1979) indicates that social networks help the network members obtain social capital and act as an information transmission channel [6]. Cohen et al. (2008) suggest 
that social network is an important mechanism for information flows that shape asset prices in the mutual fund industry [7]. Cai and Sevilir (2012) observe that social connections improve information flow between a target and an acquirer [8]. Feng et al. (2019) argue that director networks help facilitate information exchange with prospective investors in an IPO, and director connections help the IPO firm to reduce information asymmetry [9]. Jin and Yu (2018) show that executive network may speed up information acquisition and transmission so that managers can make decisions timely and effectively, which enhance the effectiveness of corporate governance and firm value [10]. Ferris et al. (2017) indicate that the cost of information acquisition within a social network is low because information can be acquired passively during social interactions [11]. We believe that social networks can effectively promote information exchange and resource sharing between the firms in the same network, and lead to better information flows, and then relieve information asymmetry. Therefore, social networks can reduce agency costs and mitigate financial constraints by reducing information asymmetry. In summary, by integrating the logical chain, we anticipate that social networks drive corporate innovation by alleviating agency conflicts and optimizing the financing environment.

From the perspectives of the director network, the CEO network and CEOdirector ties, many studies have explored the effects of social networks on corporate governance and corporate finance [8] [9] [11]-[18]. However, in these studies the social network carrier is singular, i.e. they consider of directors' connections or CEOs' connections. In other words, social networks are limited to a single specific group of managers (directors or CEOs). Few studies have examined the impact of decision makers' social networks on corporate performance from the perspective of the corporate core management team (including directors, supervisors and executives). The upper echelons theory points out that the background characteristics of the top management team can predict the organization's strategic choices and performance [19]. According to the social capital theory, both the social relations and the social structure of the corporate management team could play a decisive role in corporate behavior [20]. Therefore, whether directors, supervisors or executives are being considered, their social network relationships and connections could all influence corporate decision-making and behavior. This paper includes all the social connections between directors, supervisors and executives among different companies in the construction of the social network and extends the "director/CEO network" commonly analyzed in the existing studies to the "core management team network", builds a denser social network with companies as nodes, and performs a deeper network structure analysis for Chinese listed companies' activities. An important observation is that the innovation strategy is one of the most important strategic decisions of a company. Studying the relationship between the corporate social network based on the core management team and corporate innovation has great theoretical value and practical significance. Based on the 
framework of social network analysis, we show that a corporate social network based on the core management team has a positive causal effect on enhancing innovation investment and innovation performance, and the conclusion is robust after controlling for endogeneity (including reverse causality and correlated omitted variables). The mediation analyses show that financial constraints play a mediating function in the process of a social network of this new type enhancing corporate innovation, while the mediating effects of agency costs are not robustly significant. Alleviating corporate financial constraints is an important influence path of the social network in improving corporate innovation. In the promotion of corporate innovation by a social network of this new type, financial constraints have a stronger and more profound impact than do agency costs, and the external financing environment, financing convenience and financial support are more important than the internal principal-agent efficiency. For brevity, our newly constructed core management team network (i.e. the corporate social network based on the core management team) is also referred to simply as the corporate social network in the following sections.

The remainder of the article is organized as follows: Section 2 presents a literature review and development of our hypotheses. Section 3 describes our sample, social network, and variables. Section 4 presents the empirical results. Conclusions and implications are in Section 5.

\section{Literature Review and Hypotheses}

\subsection{Relationship between the Social Network and Corporate Innovation}

Wellman and Berkowitz (1988) believe that the social network is a relatively stable network composed of social relations among specific groups (e.g. persons, firms or organizations) [21]. The central argument of the social network analysis is that actors are embedded in networks of interconnected social relationships that offer opportunities for and constraints on behavior [22]. Social network analysis focuses on the relationship between the actors (e.g. persons, firms or organizations) and the social network embedded by the actors. It is no longer limited to the individual-, firm-, and organization-level characteristics. The social network's characteristics and social relationships influence the actors' decision-making, behavior and performance jointly. The linkages between modern companies have become increasingly closer, which is the basis of a corporate social network. The managers' social network relationship provides the company with important social capital, which has a profound impact on corporate development. Relevant studies show that interlocking directorships and directors' social network embeddedness can significantly improve corporate performance [13] [23] [24], and social network centrality, the number of structural holes and network size are positively associated with corporate investment efficiency [10] [25] [26]. Good operating performance enables a company to invest more resources in R\&D and innovation activities, and then the company has a good chance 
of achieving higher patent outputs and stronger innovation performance with guaranteed funding.

Bouwman (2011) indicates that corporate governance practices can be disseminated across companies through interlocking directors [27]. Interlocking directors can transfer incremental knowledge to the company from the outside and can help the company absorb external knowledge. The external knowledge of directors is complementary to the internal knowledge of the company. This collision of internal and external knowledge is more likely to inspire innovation. Therefore, the sharing of directors among companies is an important factor in promoting corporate innovation. Helmers et al. (2017) focus on the Indian market and observe that the number of interlocking directors on the board can improve $R \& D$ investment and patent outputs, but the channels of influence of interlocking directors on $\mathrm{R} \& \mathrm{D}$ and patent activities are different [28]. The researchers document that information transmission through interlocking directors can enhance short-term R\&D expenditures, which is an innovation effect; in contrast, the impact of board interlocks on patent activities is mainly reflected in the process of filing for patents abroad for inventions that have already been patented domestically, which is a strategic effect. In addition to social relationships of directors, those of CEOs also have great value in terms of corporate innovation. The social connections between the $\mathrm{CEO}$ and other companies are important sources of information used by the company to make R\&D investment decisions, and the CEO's social ties are an important factor in determining the firms' innovation-seeking behaviors. Oh and Barker (2018) provide evidence that the CEO imitates the R\&D intensity of tied-to firms (i.e. a firm in which the CEO serves as an outside board member) in their own firm's R\&D decisions, and imitating relationships are stronger if the CEO has a longer tenure as a director of a tied-to firm and the tied-to firm is performing well [29]. Faleye et al. (2014) point out that the CEO's personal connections increase access to relevant network information, which encourages innovation by helping CEOs identify, evaluate and exploit innovative ideas [30]. As a result, firms with better-connected CEO invest more in $\mathrm{R} \& \mathrm{D}$ and receive more and higher-quality patents. Adams and Ferreira (2007) define a CEO-friendly board as one that is socially connected with the CEO [31]. Kang et al. (2018) observe that firms with friendly boards are awarded more patents, their patents are cited more often, and this positive relation between a friendly board and innovation is more pronounced if the firm's advisory needs are greater [32]. In other words, directors serve as valuable advisors to the CEO. The above studies show that regardless of whether a director network, a CEO network or a friendly board is being considered, the corporate social network relationship can significantly enhance corporate innovation. The more connections a company has in its social network, the greater its power and influence in its social network. The stronger a firm's ability to grasp external valuable information from tied-to firms is, the greater its chance to optimize its own innovation-related decision-making by using the information on tied-to 
firms' innovation. According to the upper echelons theory, besides directors and CEOs, other executives and supervisors in the company have decisive effects on corporate decision-making and behavior. Under the trend of networking of corporate social relations, this paper integrates the social connections among directors, supervisors and executives from the overall perspective of the corporate core management team, includes all directors, supervisors and executives in the social network construction, extends the "director/CEO network" to the "core management team network", and attempts to explore the impact of a larger and wider social network on corporate innovation (both $R \& D$ inputs and patent outputs). Because R\&D investment is the material base of innovation activities, we first examine the relationship between social networks and R\&D intensity. Patent outputs are the direct results of R\&D investment, so we further study the effects of social networks on patent performance. Social network centrality is the most important proxy used to measure the characteristics of a corporate social network. The greater the company's social network centrality is, the more numerous the company's social connections, the greater the network power, and the stronger the ability to benefit from the network. Therefore, we expect that companies with high social network centrality will have more active innovation practices, such as higher R\&D investment and better patent performance. We hypothesize the following:

H1: The corporate social network based on the core management team enhances corporate innovation.

$H \mathrm{l}$ a: Social network centrality is positively associated with $R \& D$ investment.

$H 1 b$ : Social network centrality is positively associated with patent performance.

\subsection{Influence Path between the Social Network and Corporate Innovation}

Corporate innovation is a long-term process and is filled with uncertainty. High $\mathrm{R} \& \mathrm{D}$ costs, continued risk-taking and uncertain future returns are the three pressures that companies must bear while trying to innovate. Compared with the other corporate practices, indeed, innovation activities need a great deal of money, have long development cycles and result in benefits after a few years. Liu et al. (2015) also emphasize that innovation practices are restricted by internal agency costs and external financial constraints [33].

\subsubsection{Mediating Effects of Agency Costs}

Due to the uncertainty of innovation results, R\&D investment may cause agency problems between company owners and managers [1]. Holmstrom (1989) argues that larger firms are at a comparative disadvantage in conducting highly innovative research [34]. When venture capitalists eventually withdraw, their monitoring services are no longer as valuable and the company needs to bear its own monitoring costs, which is not good for corporate innovation. Jensen and Meckling (1976) define agency costs as the sum of monitoring costs, bonding costs 
and residual loss; to a certain extent [35], Holmstrom's (1989) research can be understood to imply that agency costs impede corporate innovation [34]. Using engineering employee data of high-technology companies, Zenger (1994) observes that small firms more efficiently offer performance contracts to attract and retain engineers with higher abilities and skills and that small firms more efficiently resolve severe agency problems in $R \& D$, thus encouraging $R \& D$ activities [36]. Hall (2002) argues that in the principal-agent relationship, managers pay more attention to short-term benefits than do shareholders and avoid investing more resources in R\&D projects [37]. Consequently, a firm with significant agency conflicts would invest less in $\mathrm{R} \& \mathrm{D}$ activities. Other studies also show that management ownership, concentrated ownership and effective monitoring can reduce the agency costs associated with innovative activities, and alleviating agency conflicts is beneficial to improving $\mathrm{R} \& \mathrm{D}$ inputs and patent outputs [1] [38]. Therefore, we argue that solving agency problems and reducing agency costs are effective channels of promoting corporate innovation.

A company's social network relationship has the effect of optimizing corporate governance. Ferris et al. (2017) note that the social network provides mechanisms for information sharing and punishment for reputation loss, and these mechanisms alleviate information asymmetry and agency problems [11]. Because managers fear the threat of reputation loss, social ties weaken managerial incentives to expropriate, and reduce agency costs. Chen (2012) focuses on the social network of independent directors and observes that network characteristics alleviate the type-I agency conflicts between executives and shareholders and the type-II agency conflicts between large shareholders and minority shareholders [39]. The phenomenon is that the higher the social network centrality is, the lower the two types of agency costs.

In summary, a corporate social network can help mitigate agency conflicts, and solving agency problems can effectively enhance corporate innovation. Therefore, we hypothesize that reducing agency costs is the influence path of the social network affecting corporate innovation, and agency costs play a mediating role between social network centrality and corporate innovation. Thus, we propose the following hypothesis:

H2: The corporate social network based on the core management team enhances corporate innovation by means of the mediating effect of agency costs.

H2a: Agency costs mediate the relationship between social network centrality and $R \& D$ investment.

$H 2 b$ : Agency costs mediate the relationship between social network centrality and patent performance.

\subsubsection{Mediating Effects of Financial Constraints}

Corporate innovation needs a great deal of financial support. Although internal finance is the main determinant of $\mathrm{R} \& \mathrm{D}$ expenditures, innovative companies should not solely rely on it. External financing is very important for controlling the risk 
of R\&D investment [40]. Due to the lack of collateral value, asymmetric information problems, the uncertainty of innovation outcomes and executives' adverse selection and moral hazard, it is difficult to obtain sufficient financial support from external financing channels for corporate R\&D investment [2] [5] [37] [41] [42]. Consequently, firms' innovative practices often face severe financial constraints that cause a lack of R\&D expenditures and impede innovation and its outputs. Guariglia and Liu (2014) indicate that in transition economies (e.g. China), financial constraints have long been regarded as the major obstacle for corporate innovation [43]. Zhang et al. (2017) empirically confirm that financial constraints significantly impede R\&D investments by Chinese companies and that credit rent-seeking aggravates the restrictions of financial constraints on $\mathrm{R} \& \mathrm{D}$ investment [44]. The negative effect of financial constraints on $\mathrm{R} \& \mathrm{D}$ investment is especially prominent in smaller, younger, and low-payout firms. $\mathrm{Li}$ (2011) suggests that R\&D-intensive firms are subject to more financial constraints because information asymmetry and agency problems are more severe for these firms, and the author confirms that a financially constrained R\&Dintensive firm is more likely to suspend or discontinue R\&D projects [4]. Financial market development would increase R\&D investment by mitigating financial constraints in growing firms, which should spur innovation and lead to higher overall economic growth [2] [5]. Hsu et al. (2014) claim that a well-developed financial market contributes to reducing the financing costs, improving resource allocation efficiency, and then enhancing patent outputs [45]. In a capital market, equity financing and debt financing are the two main financing channels for companies. Based on this, Hsu et al. (2014) further examine the different impacts of equity market development and credit market development on innovation [45]. The researchers observe that companies that are more dependent on external finance exhibit a higher innovation level in countries with more developed equity markets. However, development of the credit market appears to discourage corporate innovation.

These studies document that alleviating the financial constraints of the equity market and optimizing the financing environment have significant positive effects on corporate innovation. In addition, Howell (2017) points out that receiving early-stage government $\mathrm{R} \& \mathrm{D}$ grants has a signaling effect that could ease a firm's financial constraints through a certification mechanism and have a positive impact on patenting [46]. Therefore, we believe that alleviating financial constraints is another effective channel of promoting corporate innovation.

The social network studies show that corporate social connections not only optimize corporate governance but also improve the corporate financing environment. A social network constructed by executives is a type of informal institutional arrangement and can effectively promote information exchange and resource sharing between the firms in the same network. Jin and Yu (2018) observe that the size of an executive network is negatively associated with financial constraints, and the executive network plays an important role in mitigating ex- 
ternal financial constraints [10]. The authors suggest that the executive network can effectively alleviate financial constraints because executives can promote the sharing of resources by communicating and coordinating with members of the network, which reduces the transaction costs of financing and provides a guarantee for loans. $\mathrm{Xu}$ and Cao (2016) indicate that an independent director network helps firms obtain more external environment information, and directors with central network positions play better advisory roles; thus, social networks loosen the firms' financial constraints [47]. It is clear that whether a social network is an executive network or a director network, both rich social ties and central network position are beneficial to optimizing the corporate financing environment. Following the logic that the social network alleviates financial constraints and the notion that financial constraints impede corporate innovation, we hypothesize that alleviating financial constraints is an important influence path of social networks enhancing corporate innovation, and financial constraints play a mediating role between social network centrality and corporate innovation. Thus, we hypothesize the following:

H3: The corporate social network based on the core management team enhances corporate innovation by means of the mediating effect of financial constraints.

H3a: Financial constraints mediate the relationship between social network centrality and $R \& D$ investment.

$H 3 b$ : Financial constraints mediate the relationship between social network centrality and patent performance.

Our conceptual framework is shown in Figure 1.

\section{Research Design}

\subsection{Data Sample}

We use all Chinese share markets' listed companies in the period from 2009 to 2016 as our sample, and establish a social network based on the core management team's connections, which covers the whole share market in China. To address the question of whether the core management team network affects corporate innovation, we need the following four types of data: corporate management team data, corporate financial data, corporate patent data and corporate social network data. We collect data of the first three types from the China Stock Market and Accounting Research (CSMAR) database. If management team data is missing from the CSMAR database, we supplement it by using the CNINF website (http://www.cninfo.com.cn/) and the SINA Finance website (https://finance.sina.com.cn). Our sample consists of 19,757 firm-year observations, and we collect a total of 378,540 items of core management members' occupational information. The corporate social network data are calculated on the basis of corporate management team data. We manually match, collate and code the corporate management team data and then calculate the corporate social network data (i.e. network centrality) using the Ucinet 6 software. 


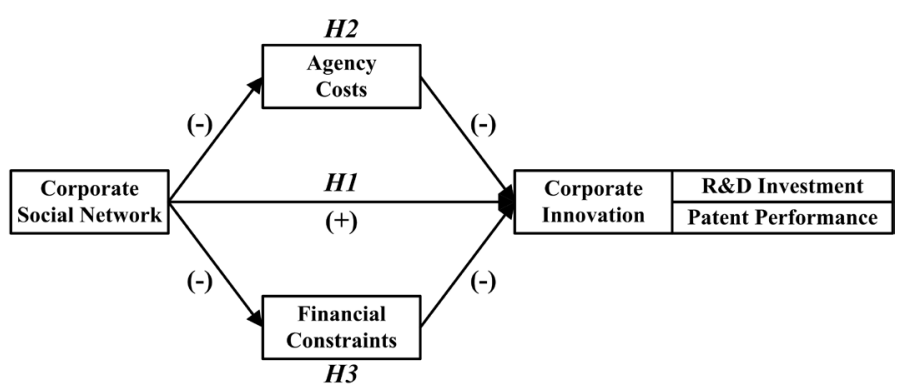

Figure 1. Conceptual framework.

\subsection{Social Network Construction}

In this paper, we define the core management members as all directors, supervisors and executives in the company. The social network connections are based on multiple appointments of corporate core management members. If a core management's member serves in two companies at the same time, we conclude that there is a social connection (also called a social tie or a social interlock) between the two companies [13] [28] [48]. The social network is composed of many unique social connections. Cai and Sevilir (2012) classify board connections into "first-degree connections" and "second-degree connections" [8]. The researchers indicate that a first-degree connection occurs if two firms share a common director, and a second-degree connection is present if one director of a firm and one director of another firm have been serving on the board of a third firm. Therefore, all social connections in this paper refer specifically to "first-degree connections". We extend the "director/CEO network" commonly considered in the existing literature to the "core management team network", which integrates all the social connections between directors, supervisors and executives among different companies and includes them in one network; thus, we can provide a wider social network analysis for Chinese listed companies' activities.

\subsection{Variable Definitions}

\subsubsection{Dependent Variables: Corporate Innovation Measures}

The prior studies of corporate innovation mainly develop two types of proxies: innovation input and innovation output. The former measures the firms' support for research and development, and R\&D expenditure is a representative variable [30]. Innovation output is a measure of the research and development achievements, and captures the quality of innovation more accurately. The main proxy of innovation output is patenting activities, including patent applications and patent citations [49]. Because companies need to go through a strict review process to apply for and receive patents, the number of patent applications and citations are more effective variables for measuring the success of corporate innovation. Pakes (1985) emphasizes that patents are an output of R\&D investments and R\&D activities, and there is a high correlation between $R \& D$ inputs and patent outputs [50]. Much empirical evidence proves that R\&D intensity is 
positively associated with the quantity and quality of patents, and continuous $R \& D$ investments enhance innovation [30] [49] [51] [52] [53]. In summary, we construct two measures of corporate innovation (Innovation) from the perspective of R\&D investment and patent performance.

The first proxy is the investment intensity of research and development $(R \& D)$, which captures the level of innovation input. We define $R \& D$ as the ratio of $\mathrm{R} \& \mathrm{D}$ expenditures to operating income and set $R \& D$ to 0 if the CSMAR database reports $\mathrm{R} \& \mathrm{D}$ expenditures as missing. The second proxy is patent performance (Patent), which captures the level of innovation output. The State Intellectual Property Office (SIPO) of China does not require references when applications for patents are submitted; in contrast, the United States Patent and Trademark Office (USPTO) requires all patent applications to provide references. Therefore, we cannot collect patent citation data in China; in other words, we cannot calculate the number of citations per patent. However, SIPO computes the number of patent applications (Apply), the number of granted patents (Grant) and the number of valid patents (Valid). Hence, we use Apply, Grant and Valid to capture patent performance. Fang et al. (2014) emphasize that the number of patents has a right-skewed distribution [49]; therefore, we use a natural logarithm of the sum of the patent count and $1(\ln (1+$ Patent $))$ as the main patent performance variable in the ordinary least squares (OLS) model. Above and below, we add 1 to the actual values before calculating the natural logarithm to avoid losing firm-year observations with no patents. Finally, our innovation performance variables are $\ln (1+$ Apply $), \ln (1+$ Grant $)$ and $\ln (1+$ Valid $)$. Variable $\ln (1+$ Apply $)$ is used for benchmark regression, and $\ln (1+$ Grant $)$ and $\ln (1+$ Valid) are used for robustness checks.

\subsubsection{Independent Variables: Social Network Centrality}

Social network centralities (SocialNetwork) are important proxies used to measure the characteristics of a corporate social network, and mainly include degree centrality (Degree), closeness centrality (Closeness), betweenness centrality (Betweenness) and eigenvector centrality (Eigenvector). These four variables comprehensively measure the embeddedness characteristics of firms' nodes in a social network, and can better capture the firms' network status, power and importance. Degree is the number of links of each company divided by the number of companies in the network. Betweenness is the number of shortest paths linking any two companies in the network that pass through the firm's node. Closeness is the inverse of the average distance between the firm and all other firms in the network. Eigenvector is a measure of the relative importance of a firm's node in the network; this variable is the dominant eigenvector of the sociomatrix and is used in the network literature to measure the prestige of a company [17]. To calculate social network centralities, we manually match the corporate core management team data year-by-year and construct the annual "firm-firm" adjacency matrix (i.e. an element in the adjacency matrix equals to 1 if there is a social network connection between two firms, and equals to 0 otherwise) accord- 
ing to core management members' multiple overlapping appointments (multioverlap employment), and then import the adjacency matrix into the Ucinet 6 software to calculate Degree, Closeness, Betweenness and Eigenvector. In this paper, all network centrality variables are standardized. We use Degree for the benchmark regression and use the other three network centralities for robustness checks.

When counting the number of firms' social connections, we should distinguish between person-level and firm-level connections. For example, suppose that Manager-m and Manager- $n$ are serving in Firm- $A$ and Firm-B, and Manager- $k$ is serving in Firm-A and Firm-C. Because Firm-A has three core employees tied with other firms (such as $A-m-B, A-n-B$ and $A-k-C$ ), the number of Firm-A's person-level connections is 3. Because Firm-A is tied with two firms (such as A-B and A-C), the number of Firm-A's firm-level connections is 2 . Fracassi and Tate (2012) and Cai et al. (2016) argue that the number and scale of social network connections can also be a good measure to capture the characteristics of a corporate social network [12] [54]. Therefore, we count the number of person-level connections (PLink) and that of firm-level connections (FLink) first, and then define the connection size as the number of connections plus 1 to take the natural logarithm (e.g. $\ln (1+$ PLink $)$ and $\ln (1+$ FLink $))$. Finally, we also use $\ln (1+$ PLink $)$ and $\ln (1+$ FLink $)$ for the robustness checks.

\subsubsection{Mediator Variables}

Ang et al. (2000), Singh and Davidson (2003), Li (2007), and Xu and Xu (2015) measure agency costs with the management expenses ratio $(M E R)$ that reflects the perquisite consumption and abnormal expenses of executives [55] [56] [57] [58]. The management expenses ratio is positively associated with agency costs. Following prior studies, we define $M E R$ as the ratio of management expenses to operating income.

Hadlock and Pierce (2010) construct a measure of financial constraints that is based solely on firm size and age, and is called the SA index [59]. This SA index is calculated as $(-0.737 \times$ Size $)+\left(0.043 \times\right.$ Size $\left.^{2}\right)-(0.04 \times$ Age $)$, where Size equals the natural logarithm of total assets, and Age is the number of years the firm has been listed. Hao and Li (2016) consider the SA index to arguably be the most exogenous financial constraints measure [42], as both the KZ index (Kaplan and Zingales, 1997) and WW index (Whited and Wu, 2006) are constructed partly from endogenous variables [60] [61]. Ju et al. (2013) explore the relationship between financial constraints and corporate innovation based on Chinese market data, and find that the SA index can also capture Chinese companies' financial constraints very well [62]. Hence, we also use the SA index (SA Index) to measure corporate financial constraints. It is important to note that the $S A I n$ dex is always a negative number. A larger $S A$ Index (in absolute value is smaller) indicates that a firm is faced with looser financial constraints and has a better financing environment. In contrast, a smaller $S A$ Index (in absolute value is larger) indicates that a firm is faced with more stringent financial constraints and 
has a worse financing environment.

\subsubsection{Control Variables}

Our selection of control variables follows the prior literature [30] [49] [63]. We introduce the following control variables: 1) Size is defined as the natural logarithm of total assets; 2) Lev is defined as the ratio of total liabilities to total assets; 3) $R O E$ is defined as return on equity; 4) CapitalExp is defined as the ratio of capital expenditures to total assets; 5) $T A R$ is defined as the ratio of tangible assets to total assets; 6) FCF is defined as free cash flow per share; 7) Sales is defined as operating income per share; 8) $S G R$ is defined as the growth rate of operating income; 9) Age is defined as the number of years the firm has been listed, and we use $\ln (1+A g e)$ as the control variable. Following the method of Fang et al. (2014) [49], we add lagged $R \& D$ (defined as the ratio of $R \& D$ expenditures to operating income) to control the firm's innovation input when we regress innovation performance. All continuous variables in the regression are winsorized at 1 st and 99th percentiles to mitigate the effect of outliers.

\subsection{Empirical Models}

To address the impact of the corporate social network on corporate innovation, we estimate the following:

$$
\text { Innovation }_{i, k, t}=\alpha_{0}+\alpha_{1} \text { SocialNetwork }_{i, t-1}+\sum \phi_{j} \text { Ctrls }_{j, i, t-1}+v_{t}+\mu_{k}+\varepsilon_{i, k, t}
$$

where $i$ denotes firm, $k$ denotes industry, and $t$ denotes time. The dependent variable ( Innovation $_{i, k, t}$ ) represents firm is corporate innovation in industry $k$ in year $t$. We use the investment intensity of $\mathrm{R} \& \mathrm{D}(R \& D)$ and patent performance $(\ln (1+$ Patent $)$, which consists of $\ln (1+$ Apply $), \ln (1+$ Grant $)$ and $\ln (1+$ Valid $))$ as proxies for corporate innovation. The independent variable (SocialNetwor$k_{i, t-1}$ ) denotes firm is network centrality in year $t-1$, which includes Degree, Closeness, Betweenness, Eigenvector, $\ln (1+$ PLink $)$ and $\ln (1+$ FLink $)$. Control variables $\left(\operatorname{Ctrls}_{i, t-1}\right)$ contain firm characteristics that could affect a firm's innovation, as discussed in Section 3.3.4, and all control variables are lagged by one year. $v_{t}$ and $\mu_{k}$ represent year fixed effects and industry fixed effects, respectively, and $\varepsilon_{i, k, t}$ is the random error term. Following common practices [10] [26] [39], we adopt the industry classification standard of China Securities Regulatory Commission (CSRC) of 2012. Specifically, we use the first two codes to classify industries within the manufacturing industry, and the first single code to classify other industries. In addition, $T$-statistics in all regressions are computed using robust standard errors adjusted for heteroscedasticity.

\section{Empirical Results}

\subsection{Summary Statistics}

Table 1 reports the descriptive statistics for all variables used in our regression models. On average, the sample firms' R\&D investment intensity is $2.61 \%$, i.e. $\mathrm{R} \& \mathrm{D}$ expenditures are $2.61 \%$ of operating income. In each fiscal year, the firms 
Table 1. Variable descriptive statistics.

\begin{tabular}{|c|c|c|c|c|c|}
\hline Variable & $\mathrm{N}$ & Mean & S.D. & Minimum & Maximum \\
\hline$R \& D$ & 19,757 & 0.0261 & 0.0376 & 0 & 0.2136 \\
\hline Apply & 19,757 & 25.5747 & 187.3450 & 0 & 7071 \\
\hline Grant & 19,757 & 18.3041 & 117.1661 & 0 & 3808 \\
\hline Valid & 19,757 & 74.6269 & 500.3424 & 0 & 20791 \\
\hline $\ln (1+$ Apply $)$ & 19,757 & 1.3977 & 1.5716 & 0 & 5.9349 \\
\hline $\ln (1+G r a n t)$ & 19,757 & 1.2793 & 1.4617 & 0 & 5.6168 \\
\hline $\ln (1+$ Valid $)$ & 19,757 & 2.1673 & 1.9507 & 0 & 6.9027 \\
\hline Degree & 19,757 & 0.1953 & 0.1400 & 0 & 0.6461 \\
\hline Closeness & 19,757 & 0.4380 & 0.1610 & 0 & 0.5876 \\
\hline Betweenness & 19,757 & 0.1432 & 0.1985 & 0 & 1.0567 \\
\hline Eigenvector & 19,757 & 0.8732 & 1.9562 & 0 & 13.1216 \\
\hline PLink & 19,757 & 5.4428 & 4.2418 & 0 & 39 \\
\hline FLink & 19,757 & 4.9640 & 3.6911 & 0 & 35 \\
\hline $\ln (1+$ PLink $)$ & 19,757 & 1.6283 & 0.7271 & 0 & 2.9957 \\
\hline $\ln (1+$ FLink $)$ & 19,757 & 1.5724 & 0.6940 & 0 & 2.8332 \\
\hline$M E R$ & 19,757 & 0.1062 & 0.1067 & 0 & 0.7654 \\
\hline SA Index & 19,757 & -3.4662 & 0.2607 & -4.0116 & -2.9455 \\
\hline Size & 19,757 & 21.9514 & 1.4208 & 19.0456 & 26.9609 \\
\hline Lev & 19,757 & 0.4458 & 0.2296 & 0.0447 & 1.0188 \\
\hline$R O E$ & 19,757 & 0.0735 & 0.1371 & -0.7010 & 0.4360 \\
\hline CapitalExp & 19,757 & 0.0522 & 0.0508 & 0.0001 & 0.2460 \\
\hline$T A R$ & 19,757 & 0.9354 & 0.0816 & 0.5271 & 1 \\
\hline$F C F$ & 19,757 & -0.2709 & 1.1087 & -4.8921 & 2.7842 \\
\hline Sales & 19,757 & 5.9346 & 7.0652 & 0.0793 & 44.2238 \\
\hline$S G R$ & 19,757 & 0.1945 & 0.5877 & -0.6167 & 4.3699 \\
\hline $\ln (1+A g e)$ & 19,757 & 1.9848 & 0.9323 & 0 & 3.1781 \\
\hline
\end{tabular}

apply for 25.5747 patents, 18.3041 patents are granted, and the firms hold 74.6269 valid patents. The mean values of patent performance measures $\ln (1+$ Apply $)$, $\ln (1+$ Grant $)$ and $\ln (1+$ Valid $)$ are 1.3977, 1.2793 and 2.1673, respectively. In our sample, only 1468 of 19,757 firm-year observations do not have any social connections. That is, approximately $92.57 \%$ of all listed companies have at least one connection to other companies, and social networks between companies have become increasingly common. On average, each firm has social ties with 4.9640 other firms (the mean of FLink is 4.9640), and each firm has 5.4428 core managers simultaneously serving in other firms (the mean of PLink is 5.4428). The mean value of Degree is 0.1953 , suggesting that each firm has social connections with $0.1953 \%$ of the total number of listed companies in the same year. The mean value of Closeness is 0.4380 , which indicates that each firm could reach every other firms in the whole network in an average of 228.31 steps (since the 
inverse of $0.4380 \%$ is 228.31). The mean value of Betweenness at 0.1432 means that the average probability of each firm being on the shortest path of any other two firms is $0.1432 \%$. Because Eigenvector is calculated by the eigenvalue equation, we cannot explain its network meaning directly. Eigenvector measures the importance of a single firm's node in the whole network, which reflects the extent to which a firm is connected with other highly connected firms. The average management expenses of each firm are $10.62 \%$ of the operating income (since the mean value of $M E R$ is 0.1026 ). The mean value of $S A$ Index is -3.4662 , and its quantile distribution is shown in Table 2. Compared with the SA index of Chinese companies from 1998 to 2008 calculated by Ju et al. (2013) [62], Chinese companies' financial constraints show a trend of weakening polarization from 2009 to 2016. For brevity, we omit a detailed discussion of control variables.

\subsection{Benchmark Regression}

Table 3 provides the empirical results for corporate social network centrality's effect on innovation investment and innovation performance. The results of the Hausman test indicate that the results of the fixed effects regressions should be given credence over the results of the random effects regressions. After controlling for the related factors, such as firm size, leverage ratio, profitability, cash flow and growth ability, as well as year fixed effects and industry fixed effects, the coefficients indicating the influence of social network centrality (Degree) on $\mathrm{R} \& \mathrm{D}$ investment intensity $(R \& D)$ and patent performance $(\ln (1+A p p l y))$ are significantly positive, which suggests that a high level of social network centrality can improve the firms' $R \& D$ inputs and patent outputs. These findings confirm the hypothesis $H 1$ that a company with more network connections and higher network centrality has more funds to invest in R\&D activities and has better patent performance.

\subsection{Endogenous Issues}

For the regression of social network measures on corporate innovation, there may be some endogenous issues, such as reverse causality and correlated omitted variables. To address the causal relationship of whether the corporate social network affects innovation investment and innovation performance, we use a lagged variable regression and two-stage instrumental variable least squares regression (IV-2SLS) to control for potential endogeneity.

Table 2. Quantile distribution of SA index.

\begin{tabular}{cccccccccc}
\hline Quantile of SA Index & $1 \%$ & $5 \%$ & $10 \%$ & $25 \%$ & $50 \%$ & $75 \%$ & $90 \%$ & $95 \%$ & $99 \%$ \\
\hline $\begin{array}{l}\text { Quantile value } \\
\text { in this paper }\end{array}$ & -4.012 & -3.902 & -3.833 & -3.688 & -3.432 & -3.235 & -3.154 & -3.136 & -2.946 \\
$\begin{array}{l}\text { Calculation by } \\
\text { Ju et al. (2013) }\end{array}$ & -4.999 & -4.639 & -4.313 & -3.706 & -3.398 & -3.199 & -2.933 & -2.711 & -2.255 \\
\end{tabular}


Table 3. Effect of social networks on corporate innovation.

\begin{tabular}{|c|c|c|}
\hline Variable & $R \& D_{t}$ & $\ln (1+\text { Apply })_{t}$ \\
\hline \multirow[t]{2}{*}{ Degree $_{t-1}$} & $0.0091^{\star * *}$ & $0.3551^{\star * *}$ \\
\hline & $(0.0015)$ & $(0.0754)$ \\
\hline \multirow[t]{2}{*}{$\operatorname{Size}_{t-1}$} & 0.0001 & $0.3041^{\star * *}$ \\
\hline & $(0.0002)$ & $(0.0110)$ \\
\hline \multirow{2}{*}{$L e v_{t-1}$} & $-0.0283^{* * *}$ & $-0.2627^{\star * *}$ \\
\hline & $(0.0012)$ & $(0.0525)$ \\
\hline \multirow[t]{2}{*}{$R O E_{t-1}$} & 0.0007 & $0.6015^{* * *}$ \\
\hline & $(0.0016)$ & $(0.0705)$ \\
\hline \multirow[t]{2}{*}{$R \& D_{t-1}$} & & $5.9741^{* * *}$ \\
\hline & & $(0.4041)$ \\
\hline \multirow[t]{2}{*}{ CapitalExp $p_{t-1}$} & $0.0155^{\star * *}$ & $1.6685^{\star * *}$ \\
\hline & $(0.0052)$ & $(0.2119)$ \\
\hline \multirow[t]{2}{*}{$T A R_{t-1}$} & $-0.0165^{\star * *}$ & $0.6606^{\star * *}$ \\
\hline & $(0.0036)$ & $(0.1235)$ \\
\hline \multirow[t]{2}{*}{$F C F_{t-1}$} & 0.0000 & $0.0553^{* * *}$ \\
\hline & $(0.0002)$ & $(0.0097)$ \\
\hline \multirow[t]{2}{*}{ Sales $_{t-1}$} & $-0.0003^{* * *}$ & $0.0080^{* * *}$ \\
\hline & $(0.0000)$ & $(0.0019)$ \\
\hline \multirow[t]{2}{*}{$S G R_{t-1}$} & $-0.0008^{\star *}$ & $-0.0616^{* * *}$ \\
\hline & $(0.0003)$ & $(0.0154)$ \\
\hline \multirow[t]{2}{*}{$\ln (1+A g e)_{t-1}$} & $-0.0066^{* * *}$ & $-0.1966^{* * *}$ \\
\hline & $(0.0003)$ & $(0.0141)$ \\
\hline Year Fixed Effects & YES & YES \\
\hline Industry Fixed Effects & YES & YES \\
\hline$F$ & $195.581^{\star * *}$ & $209.928^{* * *}$ \\
\hline Adj. $R^{2}$ & 0.479 & 0.393 \\
\hline Hausman Test Chi-square & $1125.74^{* * *}$ & $608.11^{\star * *}$ \\
\hline Observations & 16614 & 16614 \\
\hline
\end{tabular}

Notes: Robust standard errors are in parentheses. ${ }^{*} p<0.1 ;{ }^{* *} p<0.05 ;{ }^{* * *} p<0.01$.

There is a possibility that a firm with better innovation performance can attract other firms to establish social network connections with it. In other words, there is a reverse causality issue between social network centrality and corporate innovation. In the benchmark regression, considering the time lag of corporate innovation, we examine the impact of the social network on R\&D inputs and patent outputs by using one year lagged network centrality. In theory, the subsequent events cannot affect the previous events, and then considering a multiperiod lagged variable regression can control for potential reverse causality [28]. To further explore the multiperiod impact of social network centrality on cor- 
porate innovation, we lag Degree by two and three years and regress Equation (1) once again. The results in Table 4 show that Degree, which is lagged by two or three years, is still significantly positively associated with innovation investment $(R \& D)$ and innovation performance $(\ln (1+A p p l y))$, which indicates that the impact of social network connections on corporate innovation is not changed by reverse causality.

Table 4. Multi-period lagged variable regression.

\begin{tabular}{|c|c|c|c|c|}
\hline Variable & \multicolumn{2}{|c|}{$R \& D_{t}$} & \multicolumn{2}{|c|}{$\ln \left(1+\right.$ Apply $_{t}$} \\
\hline \multirow[t]{2}{*}{ Degree $_{t-2}$} & $0.0089^{\star * *}$ & & $0.3953^{\star * *}$ & \\
\hline & $(0.0016)$ & & $(0.0822)$ & \\
\hline \multirow[t]{2}{*}{ Degree $_{t-3}$} & & $0.0088^{\star * *}$ & & $0.3302^{\star * *}$ \\
\hline & & $(0.0018)$ & & $(0.0913)$ \\
\hline \multirow[t]{2}{*}{ Size $_{t-1}$} & 0.0001 & 0.0002 & $0.3023^{\star * *}$ & $0.3107^{\star * *}$ \\
\hline & $(0.0002)$ & $(0.0002)$ & $(0.0122)$ & $(0.0135)$ \\
\hline \multirow[t]{2}{*}{$L e v_{t-1}$} & $-0.0277^{\star * *}$ & $-0.0278^{\star * *}$ & $-0.2088^{\star * *}$ & $-0.1892^{\star * *}$ \\
\hline & $(0.0014)$ & $(0.0016)$ & $(0.0591)$ & $(0.0674)$ \\
\hline \multirow[t]{2}{*}{$R O E_{t-1}$} & 0.0015 & 0.0017 & $0.6851^{* * *}$ & $0.7248^{\star * *}$ \\
\hline & $(0.0018)$ & $(0.0020)$ & $(0.0816)$ & $(0.0898)$ \\
\hline \multirow[t]{2}{*}{$R \& D_{t-1}$} & & & $5.9119^{\star * *}$ & $6.1536^{\star * *}$ \\
\hline & & & $(0.4439)$ & $(0.5093)$ \\
\hline \multirow[t]{2}{*}{ CapitalExp $p_{t-1}$} & $0.0164^{\star * *}$ & $0.0217^{\star * *}$ & $1.7621^{\star * *}$ & $1.6478^{\star * *}$ \\
\hline & $(0.0059)$ & $(0.0069)$ & $(0.2404)$ & $(0.2762)$ \\
\hline \multirow[t]{2}{*}{$T A R_{t-1}$} & $-0.0174^{\star \star \star}$ & $-0.0151^{\star * \star}$ & $0.7586^{\star * *}$ & $0.9151^{\star * *}$ \\
\hline & $(0.0039)$ & $(0.0042)$ & $(0.1334)$ & $(0.1444)$ \\
\hline \multirow[t]{2}{*}{$F C F_{t-1}$} & -0.0001 & -0.0002 & $0.0584^{\star * *}$ & $0.0522^{\star * *}$ \\
\hline & $(0.0002)$ & $(0.0002)$ & $(0.0109)$ & $(0.0123)$ \\
\hline \multirow[t]{2}{*}{ Sales $_{t-1}$} & $-0.0003^{\star * *}$ & $-0.0003^{\star * *}$ & $0.0074^{\star * *}$ & $0.0062^{* * *}$ \\
\hline & $(0.0000)$ & $(0.0000)$ & $(0.0021)$ & $(0.0023)$ \\
\hline \multirow[t]{2}{*}{$S G R_{t-1}$} & $-0.0014^{\star * *}$ & $-0.0018^{* * *}$ & $-0.0646^{* * *}$ & $-0.0692^{\star * *}$ \\
\hline & $(0.0003)$ & $(0.0004)$ & $(0.0163)$ & $(0.0180)$ \\
\hline \multirow[t]{2}{*}{$\ln (1+A g e)_{t-1}$} & $-0.0074^{\star * *}$ & $-0.0079^{* * *}$ & $-0.2629^{* * *}$ & $-0.3262^{\star * *}$ \\
\hline & $(0.0004)$ & $(0.0005)$ & $(0.0185)$ & $(0.0235)$ \\
\hline Year Fixed Effects & YES & YES & YES & YES \\
\hline Industry Fixed Effects & YES & YES & YES & YES \\
\hline$F$ & $150.736^{\star * *}$ & $110.218^{\star * *}$ & $185.321^{* * *}$ & $156.143^{\star * *}$ \\
\hline Adj. $R^{2}$ & 0.487 & 0.494 & 0.397 & 0.399 \\
\hline Observations & 13,774 & 11,134 & 13,774 & 11,134 \\
\hline
\end{tabular}

Notes: Robust standard errors are in parentheses. ${ }^{\star} p<0.1 ;{ }^{* *} p<0.05 ;{ }^{* *} p<0.01$. 
The corporate social network in this paper is based on the core management members serving in different companies at the same time. If the scale of a company's core management team is larger, the company is more likely to connect through a social tie with other companies. Fracassi (2017) suggests that older directors or managers have more individual social relationships; thus, a core management team with a higher average age will bring more social connections to the company. Moreover, firms with larger management groups usually have a long decision-making process, and these core managers could ultimately make the best decisions for the company's development. Active innovation decisions need more executives and more time to repeatedly demonstrate their effectiveness. Balsmeier et al. (2017) and Kang et al. (2018) observe that board size has a positive correlation with $\mathrm{R} \& \mathrm{D}$ investment and patents [32] [64]. In contrast, firms with older management groups may be more conservative in their investment decisions [17]. Older executives are primarily interested in short-term performance instead of long-term $\mathrm{R} \& \mathrm{D}$ projects, and have some passive sentiment in their innovation strategy. Therefore, the average age of the core management team's members may be negatively associated with corporate innovation. In other words, the core management team's characteristics could be the omitted variables in innovation regression. We define the number of core management members (ManagerNum) as the total number of all directors, supervisors and executives in the company, and define the average age of core management members (ManagerAvgAge) as the average age of all directors, supervisors and executives. Because the number and average age of core management members have skewed distributions, we add the natural logarithm of ManagerNum and ManagerAvgAge (e.g. In(ManagerNum) and $\ln ($ ManagerAvgAge)) into our regression. Furthermore, in China each region has different industrial support policies for local firms. These regional characteristics are difficult to observe accurately in general. To address the potential endogeneity arising from unobservable regional heterogeneity, we control for region fixed effects in our benchmark model. Regressions with region fixed effects and core management team's characteristics are reported in Table 5 . These results show that the coefficients indicating the influence of social network centrality (Degree) on $\mathrm{R} \& \mathrm{D}$ investment intensity $(R \& D)$ and patent performance $(\ln (1+A p p l y))$ are still positive and significant after controlling for the region fixed effects and core management team's characteristics. As expected, $\ln ($ ManagerNum) is positively associated with $R \& D$ and $\ln (1+A p p l y)$, and $\ln ($ ManagerAvgAge) is negatively associated with $R \& D$ and $\ln (1+A p p l y)$. Our empirical results have not changed because of regional features and core management team's characteristics.

To address the potential endogeneity arising from other unobservable heterogeneity, we estimate an IV-2SLS regression. Ideally, we want instrumental variables that are correlated with the firm's social network characteristics but not with corporate innovation. Bound et al. (1995) and Angrist et al. (1996) suggest 
Table 5. Regressions with region fixed effects and core management team characteristics.

\begin{tabular}{|c|c|c|c|c|}
\hline \multirow{2}{*}{$\begin{array}{l}\text { Variable } \\
\text { Degree }_{t-1}\end{array}$} & \multicolumn{2}{|c|}{$R \& D_{t}$} & \multicolumn{2}{|c|}{$\ln (1+\text { Apply })_{t}$} \\
\hline & $0.0089^{\star * *}$ & $0.0082^{* * *}$ & $0.3378^{\star * *}$ & $0.1929^{\star *}$ \\
\hline & $(0.0016)$ & $(0.0016)$ & $(0.0759)$ & $(0.0785)$ \\
\hline \multirow[t]{2}{*}{$\ln (\text { ManagerNum })_{t-1}$} & & $0.0026^{\star *}$ & & $0.3665^{\star * *}$ \\
\hline & & $(0.0011)$ & & $(0.0485)$ \\
\hline \multirow[t]{2}{*}{$\operatorname{In}(\text { ManagerAvgAge })_{t-1}$} & & $-0.0181^{* * *}$ & & $-0.3784^{* *}$ \\
\hline & & $(0.0040)$ & & $(0.1682)$ \\
\hline \multirow[t]{2}{*}{ Size $_{t-1}$} & -0.0002 & -0.0001 & $0.3020^{\star * *}$ & $0.2875^{\star * *}$ \\
\hline & $(0.0002)$ & $(0.0002)$ & $(0.0110)$ & $(0.0114)$ \\
\hline \multirow[t]{2}{*}{$\operatorname{LeV}_{t-1}$} & $-0.0274^{* * *}$ & $-0.0279^{* * *}$ & $-0.2568^{\star * *}$ & $-0.2913^{\star * *}$ \\
\hline & $(0.0012)$ & $(0.0012)$ & $(0.0525)$ & $(0.0526)$ \\
\hline \multirow[t]{2}{*}{$R O E_{t-1}$} & 0.0010 & 0.0010 & $0.5718^{\star * *}$ & $0.5947^{\star * *}$ \\
\hline & $(0.0016)$ & $(0.0016)$ & $(0.0702)$ & $(0.0706)$ \\
\hline \multirow[t]{2}{*}{$R \& D_{t-1}$} & & & $5.8057^{\star * *}$ & $5.7031^{* * *}$ \\
\hline & & & $(0.3983)$ & $(0.3965)$ \\
\hline \multirow[t]{2}{*}{ CapitalExp $p_{t-1}$} & $0.0161^{\star * *}$ & $0.0162^{* * *}$ & $1.6504^{* * *}$ & $1.6539^{* * *}$ \\
\hline & $(0.0052)$ & $(0.0052)$ & $(0.2100)$ & $(0.2098)$ \\
\hline \multirow[t]{2}{*}{$T A R_{t-1}$} & $-0.0152^{\star * *}$ & $-0.0143^{* * *}$ & $0.7233^{\star * *}$ & $0.7388^{\star * *}$ \\
\hline & $(0.0036)$ & $(0.0036)$ & $(0.1246)$ & $(0.1251)$ \\
\hline \multirow[t]{2}{*}{$F C F_{t-1}$} & -0.0000 & 0.0000 & $0.0532^{* * *}$ & $0.0541^{\star * *}$ \\
\hline & $(0.0002)$ & $(0.0002)$ & $(0.0097)$ & $(0.0097)$ \\
\hline \multirow[t]{2}{*}{ Sales $_{t-1}$} & $-0.0003^{* * *}$ & $-0.0003^{* * *}$ & $0.0057^{\star \star \star}$ & $0.0056^{* * *}$ \\
\hline & $(0.0000)$ & $(0.0000)$ & $(0.0019)$ & $(0.0019)$ \\
\hline \multirow[t]{2}{*}{$S G R_{t-1}$} & $-0.0007^{\star *}$ & $-0.0009^{\star * *}$ & $-0.0552^{\star * *}$ & $-0.0609^{\star * *}$ \\
\hline & $(0.0003)$ & $(0.0003)$ & $(0.0153)$ & $(0.0154)$ \\
\hline \multirow[t]{2}{*}{$\ln (1+A g e)_{t-1}$} & $-0.0063^{* * *}$ & $-0.0062^{* * *}$ & $-0.1667^{\star * *}$ & $-0.1679^{\star * *}$ \\
\hline & $(0.0003)$ & $(0.0003)$ & $(0.0140)$ & $(0.0142)$ \\
\hline Year Fixed Effects & YES & YES & YES & YES \\
\hline Industry Fixed Effects & YES & YES & YES & YES \\
\hline Region Fixed Effects & YES & YES & YES & YES \\
\hline$F$ & $182.613^{* * *}$ & $153.608^{\star * *}$ & $184.563^{* * *}$ & $162.721^{* * *}$ \\
\hline Adj. $R^{2}$ & 0.485 & 0.486 & 0.409 & 0.411 \\
\hline Observations & 16,614 & 16,614 & 16,614 & 16,614 \\
\hline
\end{tabular}

Notes: Robust standard errors are in parentheses. ${ }^{\star} p<0.1 ;{ }^{* *} p<0.05 ;{ }^{* *} p<0.01$. 
that instrumental variables have no effect on the outcome except through the endogenous variable, and the correlation between instruments and disturbances in the standard econometric formulation is random or ignorable [65] [66]. Following Ferris et al. (2017) and Zhang et al. (2017) [11] [44], we develop our first instrumental variable avgRegionDegree, defined as the average social network centrality (Degree) of other listed companies (excluding the target firm) located within the same geographic region (i.e. province or municipality in China). Because of similar environments in the same regions, the social network characteristics of other firms are likely to influence the target firm's social network characteristics. We argue that the target firm's social network centrality is positively correlated with other firms' average social network centrality. Normally, the individual characteristics of other firms cannot affect the target firm's decision-making and performance, and thus avgRegionDegree could be an effective instrument to study $R \& D$ inputs and patent outputs. Following Chuluun et al. (2017) and Feng et al. (2019) [9] [48], we develop our second instrumental variable In(FirmNumRegion), defined as the natural logarithm of the number of listed companies located within the same geographic region as the target firm. A target firm is more likely to network with other firms within geographic proximity due to shared experiences, both professional and other. If the number of firms in one region is larger, the target firm has a higher likelihood of connecting through a social tie with other firms. We suggest that the target firm's social network centrality is positively correlated with the logarithm of number of firms in the same region. Because In (FirmNumRegion) is an external measure that covers a wide range of firms across industries in the entire region, the theoretical relationship between $\ln$ (FirmNumRegion) and corporate innovation is likely quite weak. Overall, we anticipate that the two instrumental variables are exogenous and have no significant correlation with corporate innovation, at least in theory.

The IV-2SLS regression results of social network centrality on corporate innovation are shown in Table 6. Instrumental variables avgRegionDegree and In (FirmNumRegion) have passed the underidentification test, weak identification test and overidentification test, suggesting that our instrumental variables are both relevant and effective. In the 1-stage regression, avgRegionDegree and In(FirmNumRegion) are positively associated with Degree, which means that a firm with higher other firms' average social network centrality and a larger number of firms in the same region has a larger social network centrality. In the 2-stage regression, the instrumented Degree has a significant positive impact on $\mathrm{R} \& \mathrm{D}$ inputs $(\mathrm{R} \& \mathrm{D})$ and patent outputs $(\ln (1+A p p l y))$, as before. The IV-2SLS regression results are consistent with the benchmark regression (Table 3 ). Therefore, we believe that there is a causal relationship between social networks and corporate innovation. Specifically, a company with a central position in a social network has higher innovation investment and better innovation performance. 
Table 6. IV-2SLS regression.

\begin{tabular}{|c|c|c|c|c|}
\hline \multirow{2}{*}{ Variable } & 1-Stage & 2-Stage & 1-Stage & 2-Stage \\
\hline & Degree $_{t-1}$ & $R \& D_{t}$ & Degree $_{t-1}$ & $\ln \left(1+\right.$ Apply $_{t}$ \\
\hline \multirow[t]{2}{*}{ avgRegionDegree $_{t-1}$} & $0.5230^{\star * *}$ & & $0.5211^{\star * *}$ & \\
\hline & $(0.0370)$ & & $(0.0370)$ & \\
\hline \multirow[t]{2}{*}{$\operatorname{In}(\text { FirmNumRegion })_{t-1}$} & $0.0106^{* * *}$ & & $0.0104^{\star * *}$ & \\
\hline & $(0.0013)$ & & $(0.0013)$ & \\
\hline \multirow[t]{2}{*}{ Degree $_{t-1}$} & & $0.0460^{\star \star \star}$ & & $1.0642^{\star *}$ \\
\hline & & $(0.0098)$ & & $(0.4663)$ \\
\hline \multirow[t]{2}{*}{$\ln (\text { ManagerNum })_{t-1}$} & $0.1567^{\star * *}$ & -0.0026 & $0.1559^{* * *}$ & $0.2128^{\star *}$ \\
\hline & $(0.0048)$ & $(0.0018)$ & $(0.0048)$ & $(0.0871)$ \\
\hline \multirow[t]{2}{*}{$\ln (\text { ManagerAvgAge })_{t-1}$} & $0.0822^{\star * *}$ & $-0.0211^{\star * *}$ & $0.0852^{\star * \star}$ & $-0.6693^{* * *}$ \\
\hline & $(0.0172)$ & $(0.0042)$ & $(0.0172)$ & $(0.1740)$ \\
\hline \multirow[t]{2}{*}{ Size $_{t-1}$} & $0.0145^{\star * *}$ & $-0.0004^{\star}$ & $0.0145^{\star * *}$ & $0.2807^{\star * *}$ \\
\hline & $(0.0011)$ & $(0.0003)$ & $(0.0011)$ & $(0.0134)$ \\
\hline \multirow[t]{2}{*}{$\operatorname{LeV}_{t-1}$} & -0.0087 & $-0.0283^{* * *}$ & -0.0044 & $-0.2952^{* * *}$ \\
\hline & $(0.0055)$ & $(0.0013)$ & $(0.0057)$ & $(0.0531)$ \\
\hline \multirow[t]{2}{*}{$R O E_{t-1}$} & $0.0213^{\star * *}$ & -0.0001 & $0.0221^{\star * *}$ & $0.6019^{\star * *}$ \\
\hline & $(0.0077)$ & $(0.0016)$ & $(0.0077)$ & $(0.0726)$ \\
\hline \multirow[t]{2}{*}{$R \& D_{t-1}$} & & & $0.1556^{\star * *}$ & $5.6928^{* * *}$ \\
\hline & & & $(0.0349)$ & $(0.4121)$ \\
\hline \multirow[t]{2}{*}{ CapitalExp $p_{t-1}$} & 0.0103 & $0.0149^{* * *}$ & 0.0075 & $1.6587^{\star * *}$ \\
\hline & $(0.0218)$ & $(0.0053)$ & $(0.0218)$ & $(0.2117)$ \\
\hline \multirow[t]{2}{*}{$T A R_{t-1}$} & 0.0146 & $-0.0160^{* * *}$ & 0.0173 & $0.6805^{\star * *}$ \\
\hline & $(0.0145)$ & $(0.0036)$ & $(0.0145)$ & $(0.1245)$ \\
\hline \multirow[t]{2}{*}{$F C F_{t-1}$} & $0.0022^{* *}$ & -0.0000 & $0.0022^{\star *}$ & $0.0549^{* * *}$ \\
\hline & $(0.0011)$ & $(0.0002)$ & $(0.0011)$ & $(0.0098)$ \\
\hline \multirow[t]{2}{*}{ Sales $_{t-1}$} & $0.0003^{\star}$ & $-0.0003^{\star * *}$ & $0.0004^{* *}$ & $0.0075^{* * *}$ \\
\hline & $(0.0002)$ & $(0.0000)$ & $(0.0002)$ & $(0.0019)$ \\
\hline \multirow[t]{2}{*}{$S G R_{t-1}$} & 0.0015 & $-0.0010^{* * *}$ & 0.0016 & $-0.0699^{* * *}$ \\
\hline & $(0.0018)$ & $(0.0003)$ & $(0.0018)$ & $(0.0156)$ \\
\hline \multirow[t]{2}{*}{$\ln (1+A g e)_{t-1}$} & $0.0097^{\star * *}$ & $-0.0068^{\star * *}$ & $0.0107^{\star * *}$ & $-0.2030^{* * *}$ \\
\hline & $(0.0014)$ & $(0.0003)$ & $(0.0014)$ & $(0.0151)$ \\
\hline Year Fixed Effects & YES & YES & YES & YES \\
\hline Industry Fixed Effects & YES & YES & YES & YES \\
\hline Kleibergen-Paap rk LM & $345.993^{* * *}$ & & $339.312^{* * *}$ & \\
\hline Kleibergen-Paap rk Wald F & $187.462^{* * *}$ & & $183.549^{* * *}$ & \\
\hline Hansen J & & 0.427 & & 1.198 \\
\hline$F$ & $211.837^{* * *}$ & $156.454^{* * *}$ & $198.697^{* * *}$ & $182.096^{* * *}$ \\
\hline Adj. $R^{2}$ & 0.213 & 0.464 & 0.214 & 0.390 \\
\hline Observations & 16,614 & 16,614 & 16,614 & 16,614 \\
\hline
\end{tabular}

Notes: Robust standard errors are in parentheses. ${ }^{*} p<0.1{ }^{* *} p<0.05$; ${ }^{* *} p<0.01$. 


\subsection{Mediation Analyses}

To examine the mediating effects of agency costs and financial constraints in the process of social networks promoting corporate innovation, we perform a mediation analysis following the bootstrapping procedures, as elucidated by Preacher and Hayes (2008) and Zhao et al. (2010) [67] [68]. The results of the mediation analysis and bootstrap estimate (based on 5000 bootstrap samples) are reported in Table 7. In Row 1 of Table 7, the indirect effect of the social network (Degree) improving $\mathrm{R} \& \mathrm{D}$ investment $(R \& D)$ through agency costs $(M E R)$ is not significant, with a point estimate of -0.0004 and two $95 \%$ confidence intervals including 0 (both the normal distribution-based confidence interval and the bias-corrected confidence interval). This indicates that agency costs do not mediate the relationship between the social network and R\&D investment. In Row 2 of Table 7, the indirect effect of the social network (Degree) enhancing patent performance $(\ln (1+$ Apply $))$ through agency costs $(M E R)$ is not robustly significant, with a point estimate of 0.0026 and a $95 \%$ normal distribution-based confidence interval including 0 . Although the $95 \%$ bias-corrected confidence interval excludes 0 , we judge that this result is not robust and agency costs do not play a significant mediating role between the social network and patent performance. Therefore, our empirical tests of the hypothesis $H 2$ have failed. Agency costs do not mediate the relationship between the corporate social network and corporate innovation. Alleviating agency conflicts is not an influence path of the social network driving corporate innovation.

In Row 3 and Row 4 of Table 7, the indirect effects of social network (Degree) promoting corporate innovation (both $R \& D$ and $\ln (1+A p p l y)$ ) through financial constraints (SA Index) are robustly significant, with two $95 \%$ confidence intervals excluding 0 (both the normal distribution-based confidence interval and the bias-corrected confidence interval). These results indicate that financial constraints mediate the relationship between the social network and corporate innovation (both $R \& D$ inputs and patent outputs) significantly. To summarize, financial constraints have a real mediating effect in the process of the corporate social network enhancing corporate innovation, and mitigation of financial constraints is an important influence path of the social network promoting corporate innovation. Our empirical evidence supports the hypothesis $H 3$ completely.

Table 7. Mediation analysis of bootstrapping procedures.

\begin{tabular}{|c|c|c|c|c|c|}
\hline \multirow{2}{*}{$\begin{array}{l}\text { Mediator } \\
\text { Variable }\end{array}$} & \multirow{2}{*}{$\begin{array}{l}\text { Mediating } \\
\text { Path }\end{array}$} & \multirow{2}{*}{$\begin{array}{l}\text { Indirect } \\
\text { Effect }\end{array}$} & \multirow{2}{*}{$\begin{array}{c}\text { Bootstrap } \\
\text { S.E. }\end{array}$} & \multicolumn{2}{|c|}{ 95\% Confidence Interval } \\
\hline & & & & Normal-Based & Bias-Corrected \\
\hline \multirow{2}{*}{$M E R$} & Degree $\rightarrow R \& D$ & -0.000395 & 0.000358 & {$[-0.001097,0.000306]$} & {$[-0.001087,0.000318]$} \\
\hline & Degree $\rightarrow \ln (1+$ Apply $)$ & 0.002638 & 0.001561 & {$[-0.000422,0.005698]$} & {$[0.000412,0.006794]$} \\
\hline \multirow{2}{*}{ SA Index } & Degree $\rightarrow R \& D$ & 0.000240 & 0.000100 & {$[0.000045,0.000435]$} & {$[0.000055,0.000457]$} \\
\hline & Degree $\rightarrow \ln (1+$ Apply $)$ & 0.017369 & 0.008286 & {$[0.001128,0.033610]$} & {$[0.000459,0.033208]$} \\
\hline
\end{tabular}

Notes: Based on 5000 bootstrap samples. 


\subsection{Robustness Checks}

\subsubsection{Are the Effects of Social Networks on Corporate Innovation Monotonic?}

Fich and Shivdasani (2006) note that a busy board is formed when the majority of outside directors hold three or more directorships [69]. Because the directors' attention is dispersed, a busy board cannot execute the monitoring function very well. A firm with a busy board is correlated with a weak corporate governance and displays a lower firm value. The social network relationship in this paper is established by the core management members' multioverlap employment. It is worth further discussing whether too many corporate social connections impede corporate innovation and whether the effects of social networks on corporate innovation are monotonic.

We examine the inverted U-shaped relationship between the social network and corporate innovation following the method of Lind and Mehlum (2010) and Haans et al. (2016) [70] [71]. The results are reported in Table 8. First, we show that the data range of Degree is 0 to 0.6461 in our sample. Second, we test the significance of the direct and squared terms of Degree. Regardless of whether we consider the $R \& D$ regression or the $\ln (1+$ Apply) regression, Degree is significantly positive and Degree is significantly negative. Third, we test whether the slope at both ends of the data range is sufficiently steep. The slope at the minimum value of Degree is positive and significant in both the $R \& D$ regression and the $\ln (1+$ Apply $)$ regression, but the slope at the maximum value of Degree is negative and not significant. This indicates that the true relationship between the social network and corporate innovation may be merely one half of an inverted U-shape. Fourth, we test whether the extreme point (also called the turning point) is located well within the data range. The extreme point estimates of Degree in the $R \& D$ regression and the $\ln (1+A p p l y)$ regression are 0.4774 and 0.4587 , respectively. Then, we calculate the extreme point's confidence interval; results show that the upper bound of the $95 \%$ confidence interval of the extreme point based on the Fieller method, in both the $R \& D$ regression and the $\ln (1+$ Apply) regression, is outside the Degree range. The confidence intervals confirm that only one half of the inverted U-shaped curve is revealed in our data range. In summary, there is no significant inverted U-shaped relationship between the social network and corporate innovation. In other words, we have the left half of the inverted $\mathrm{U}$-shaped curve in our data range, and the relationship between social network and corporate innovation is robustly monotonic. This means that we indirectly capture the robust positive impact of the social network on corporate innovation. Having too many social connections will not impede corporate innovation. The corporate social network has a monotonic positive effect in enhancing $\mathrm{R} \& \mathrm{D}$ investment and patent performance.

\subsubsection{Robustness Checks of Changing Samples or Variables}

We use four methods to perform robustness checks. First, we change the sample to re-estimate the above models. Considering the different attitudes of various 
Table 8. Test of an inverted U-Shaped relationship between social networks and corporate innovation.

\begin{tabular}{ccc}
\hline Dependent Variable & $R \& D$ & $\ln (1+$ Apply $)$ \\
\hline Data range of Degree & {$[0,0.6461]$} & {$[0,0.6461]$} \\
Significance of Degree & $0.0196^{* * *}$ & $0.8017^{* * *}$ \\
Significance of Degree & $(0.0042)$ & $(0.1992)$ \\
& $-0.0205^{* * *}$ & $-0.8737^{* *}$ \\
Slope at minimum value of Degree & $(0.0075)$ & $(0.3807)$ \\
Slope at maximum value of Degree & 0.0196 & 0.8017 \\
Extreme point & {$[0.000]$} & {$[0.000]$} \\
95\% Confidence interval-Fieller method & -0.0069 & -0.3275 \\
& {$[0.121]$} & {$[0.150]$} \\
\end{tabular}

Notes: Robust standard errors are in parentheses and $p$-values are in square brackets. ${ }^{\star} p<0.1 ;{ }^{* *} p<0.05$; ${ }^{* * *} p<0.01$.

industries to innovation, we explore the impact of social networks on corporate innovation in a nonfinancial industry subsample and a manufacturing industry subsample instead of the whole sample. Second, we construct several alternative measures of corporate innovation and re-estimate the above models. For innovation input, we define $R \& D$ investment as the ratio of $R \& D$ expenditures to total assets, or the ratio of $R \& D$ expenditures to cash received from sales of goods or rendering of services. For innovation output, we define patent performance as the number of granted patents plus 1 to take the natural logarithm, the number of valid patents plus 1 to take the natural logarithm, or the number of patent applications that have been granted plus 1 to take the natural logarithm. Third, we use the other social network proxies mentioned in Section 3.3 to measure the firm's embeddedness characteristics and re-estimate the above models. These substitution variables include closeness centrality, betweenness centrality, eigenvector centrality, person-level connection size and firm-level connection size. Fourth, we select several alternative measures of mediator variables and re-estimate the mediation models. For agency costs, we use the efficiency of asset utilization, CEO duality, independence of the board, stock shares held by the core management team and the separation between control rights and cash flow rights instead of the management expense ratio [33] [55] [56] [72] [73]. For financial constraints, we use the KZ index and the WW index instead of the SA index [60] [61]. The results of all robustness tests remain substantially unchanged; these results are not reported here for brevity. In summary, a firm that has more social ties, higher network centrality, better connection quality, a shorter connection path and a stronger ability to control the shortest path makes a greater innovation investment and has a stronger innovation performance. Financial constraints 
play a mediating role in the process of corporate social network driving corporate innovation, but agency costs do not.

\section{Conclusions and Implications}

Under the background of networking of corporate social relations, the influence of corporate innovation activities has broken through simple stakeholder boundaries. Corporate innovation-related decision-making and innovation behavior will spread widely throughout the social network. Corporate innovation investment and innovation performance are not only constrained by firm-level operating characteristics but are also affected by the corporate social network. We consider all Chinese share markets' listed companies in the period from 2009 to 2016 as our sample, and establish a new type of social network based on the core management team's connections (i.e. we include all the social connections between directors, supervisors and executives among different companies in the social network construction), which covers the whole share market in China. In this paper, we empirically analyze the impact of this new type of corporate social network on innovation activities (both $R \& D$ inputs and patent outputs). Next, we explore the potential influence path of this new type of social network driving corporate innovation from the perspective of two channels of agency costs and financial constraints.

Our empirical results suggest that the corporate social network based on the core management team has a positive causal effect on enhancing $R \& D$ inputs and patent outputs, and the relationship between social networks and corporate innovation is robustly monotonic. A firm that has more social ties, higher network centrality, better connection quality, a shorter connection path and a stronger ability to control the shortest path, makes a greater innovation investment and has a stronger innovation performance. These results are robust after controlling for endogenous issues (including reverse causality and correlated omitted variables). The mediation analyses show that our newly constructed core management team network is beneficial to loosening financial constraints, and optimizing the financing environment is the key to improving corporate innovation. Alleviating financial constraints plays a mediating role in the process of this new type of social network driving corporate innovation, while mitigating agency conflicts does not. In the promotion of corporate innovation by the corporate social network, financial constraints have a more profound impact than agency costs. Our findings agree with those of Liu et al. (2015) that the influence of financial constraints is stronger than that of agency costs in the practice of corporate R\&D [33]. The above conclusions show that the influence of our newly constructed core management team network on corporate innovation is all-encompassing, and more importantly, such social network could drive corporate innovation jointly from the following two different aspects: innovation input and innovation output. Financial constraints, rather than agency costs, have a significant mediating effect in the process of improving innovation investment and promoting inno- 
vation performance by the corporate social network based on the core management team. Alleviating financial constraints and optimizing the financing environment, which is called the financial constraints channel, is the important influence path of the social network boosting corporate innovation.

The relationship between the listed company and the corporate social network is similar to that between an individual and a collective. Many individuals join together to form a collective, and the collective has significant influence on both individual decision-making and individual behavior. The embeddedness and structural characteristics of the social network provide competitive advantages for socially connected firms, such as promoting information sharing, improving external monitoring, alleviating agency conflicts, optimizing the financing environment, etc. These advantages build the foundation for enhancing corporate innovation. Our achievements in this paper provide a new direction and thinking for listed companies to make innovation and corporate governance decisions and have some practical value, as follows: 1) For corporate innovation decision-making, managers could collect valuable external information through the social network based on the core management team and utilize socially connected firms' R\&D information to optimize their own innovation decisions. The corporate social network is beneficial to reduce decision-making costs and promote decision-making efficiency and then improve innovation performance. 2) For corporate governance, rich social connections and central network positions build unique information advantages for the company. A firm with higher network centrality has more opportunities to obtain other firms' internal information. To a certain extent, constructing social network relationships reduces the corporate information asymmetry from inside and outside, and then strengthens the corporate competitive advantages. 3) Corporate behavior can be spread widely in the social network. Companies with strong network influences should take the lead to actively engage in creative practices and drive other firms to innovate together. As a result, we expect that the social multiplier effect of innovation diffusion will come true. 4) The primary factor impeding corporate innovation is the serious financial constraints faced by the firm. The government should actively optimize the corporate financing environment by improving the operating environment and promoting marketization and enhance corporate independent innovation. Eventually, with the support of state policies, Chinese companies will accomplish the great mission of mass entrepreneurship and innovation.

This study contributes to the existing literature in two ways. First, in the construction of the social network, we integrate all the social connections between directors, supervisors and executives among different companies and include them in one network, extending the "director/CEO network" to the "core management team network", and establishing a denser social network with companies as nodes. In essence, whether it's a director network, CEO network or core management team network, they are all social networks. As we all known, directors and CEOs are the most important managers and decision makers in en- 
terprises. Meanwhile, the upper echelons theory emphasizes that other executives and supervisors in the company also have decisive effects on corporate decision-making and behavior. Therefore, we believe that the impact of social networks based on other executives and supervisors on corporate activities should not be ignored. Most of the existing researches on corporate social network are based on a single network carrier, such as director network or CEO network. The director network focuses on the "director-director" connections between different companies, and the CEO network focuses on the "CEO-CEO" connections. However, the relationship between a director of one company and a CEO of another company also contains incremental information. Oh and Barker (2018) find that when a CEO serves as an outside director in other companies, CEO imitates the R\&D intensity of tied-to firms in their own firm's R\&D decisions [29]. This indicates that the "CEO-outside director" connection provides valuable information about corporate innovation. In other empirical studies of social network with single carrier on corporate innovation, Helmers et al. (2017) and Chuluun et al. (2017) document that director network can promote corporate innovation [28] [48]. Nevertheless, $\mathrm{Yu}$ and $\mathrm{He}$ (2019) argue that the independent director network and supervisor network have no significant effects on innovation investment [74]. In our opinion, $\mathrm{Yu}$ and $\mathrm{He}$ (2019) ignore the connections between independent director and executive or supervisor, or the connections between supervisor and director or executive, so they do not draw a significant empirical conclusion. Consequently, we believe that integrating all the social connections between directors, supervisors and executives among different companies has theoretical and practical value for researches on corporate innovation from the perspective of social networks. In addition to the connections of "director-director" and "CEO-CEO", the connections of "director-executive", "director-supervisor", "executive-executive”, "executive-supervisor” and "supervisor-supervisor" among different companies can also carry lots of information related to innovation. This paper constructs social network based on the above six kinds of network carriers ("CEO-CEO" connection is a kind of "executive-executive" connections) and includes all connections between directors, supervisors and executives among different companies. This new type of social network can dig and exhibit more valuable information between company connections, and provides a wider and deeper network structure analysis for Chinese listed companies' innovation activities.

Second, we explore two specific influence channels of how the social network based on the core management team drives corporate innovation, and successfully confirm a significant mediating path. To keep competitive advantages, enterprises spend a lot of human resources, material resources and financial resources to carry out innovation activities. Due to the opacity of R\&D process between shareholders and managers, and the information asymmetry between inside and outside the companies, the internal agency problem and external financial constraints impede the promotion of innovation ability and corporate 
sustainability [1] [43]. In terms of positive externalities of social networks, some studies suggest that social networks can improve corporate governance and optimize financing environment [10] [11]. Therefore, we integrate social networks, corporate innovation, agency costs and financial constraints into a unified analysis framework to empirically test whether social networks can influence corporate innovation through "agency costs channel" or "financial constraints channel". The results show that the corporate social network based on the core management team can significantly enhance corporate innovation, and financial constraints play a mediating role in the process of social networks driving innovation. By contrast, agency costs have no significant mediating effects between social networks and corporate innovation. Our mediation analyses identify a clear path of social networks influencing innovation, that is, there is a "financial constraints channel" for social networks to drive corporate innovation. Firms with rich social network connections can alleviate the external financial constraints by reducing the information asymmetry between inside and outside the companies. The financing environment with weak financial constraints is helpful for firms to raise funds for R\&D activities, thus promoting the corporate innovation level. Compared with financial constraints, agency costs do not build a bridge between social networks and corporate innovation. That is to say, the promotion of social networks on innovation ability is not through improving corporate governance. There is no "agency costs channel" for social network to affect corporate innovation. In summary, for the improvement of corporate innovation ability, the external financing environment, financing convenience and financial support are more important than the internal principal-agent efficiency. Alleviating financial constraints through the core management team network is an effective governance path to improving corporate innovation.

\section{Funding}

This research is supported by the National Social Science Fund of China (grant number: 16BGL004).

\section{Conflicts of Interest}

The authors declare no conflicts of interest regarding the publication of this paper.

\section{References}

[1] Block, J.H. (2012) R\&D Investments in Family and Founder Firms: An Agency Perspective. Journal of Business Venturing, 27, 248-265. https://doi.org/10.1016/j.jbusvent.2010.09.003

[2] Brown, J.R., Martinsson, G. and Petersen, B.C. (2012) Do Financing Constraints Matter for R\&D? European Economic Review, 56, 1512-1529. https://doi.org/10.1016/j.euroecorev.2012.07.007

[3] Yoo, T. and Rhee, M. (2013) Agency Theory and the Context for R\&D Investment: Evidence from Korea. Asian Business and Management, 12, 227-252. 
https://doi.org/10.1057/abm.2013.2

[4] Li, D. (2011) Financial Constraints, R\&D Investment, and Stock Returns. Review of Financial Studies, 24, 2974-3007. https://doi.org/10.1093/rfs/hhr043

[5] Borisova, G. and Brown, J.R. (2013) R\&D Sensitivity to Asset Sale Proceeds: New Evidence on Financing Constraints and Intangible Investment. Journal of Banking and Finance, 37, 159-173. https://doi.org/10.1016/j.jbankfin.2012.08.024

[6] Freeman, L. (1979) Centrality in Social Networks: Conceptual Clarification. Social Networks, 1, 215-239. https://doi.org/10.1016/0378-8733(78)90021-7

[7] Cohen, L., Frazzini, A. and Malloy, C. (2008) The Small World of Investing: Board Connections and Mutual Fund Returns. Journal of Political Economy, 116, 951-979. https://doi.org/10.1086/592415

[8] Cai, Y. and Sevilir, M. (2012) Board Connections and M\&A Transactions. Journal of Financial Economics, 103, 327-349. https://doi.org/10.1016/j.jfineco.2011.05.017

[9] Feng, Y., Song, K. and Tian, Y.S. (2019) Director Networks and Initial Public Offerings. Journal of Banking and Finance, 106, 246-264. https://doi.org/10.1016/j.jbankfin.2019.07.001

[10] Jin, X. and Yu, J. (2018) Government Governance, Executive Networks and Corporate Investment Efficiency. China Finance Review International, 8, 122-139. https://doi.org/10.1108/CFRI-06-2016-0053

[11] Ferris, S.P., Javakhadze, D. and Rajkovic, T. (2017) The International Effect of Managerial Social Capital on the Cost of Equity. Journal of Banking and Finance, 74, 69-84. https://doi.org/10.1016/j.jbankfin.2016.10.001

[12] Fracassi, C. and Tate, G. (2012) External Networking and Internal Firm Governance. Journal of Finance, 67, 153-194.

https://doi.org/10.1111/j.1540-6261.2011.01706.x

[13] Larcker, D.F., So, E.C. and Wang, C.C.Y. (2013) Boardroom Centrality and Firm Performance. Journal of Accounting and Economics, 55, 225-250.

https://doi.org/10.1016/j.jacceco.2013.01.006

[14] El-Khatib, R., Fogel, K. and Jandik, T. (2015) CEO Network Centrality and Merger Performance. Journal of Financial Economics, 116, 349-382. https://doi.org/10.1016/j.jfineco.2015.01.001

[15] Jin, X., Lei, G.Y. and Yu, J.L. (2016) Government Governance, Executive Networks and Enterprise R\&D Expenditure. China Journal of Accounting Research, 9, 59-81. https://doi.org/10.1016/j.cjar.2015.09.001

[16] Fahlenbrach, R., Low, A. and Stulz, R.M. (2017) Do Independent Director Departures Predict Future Bad Events? Review of Financial Studies, 30, 2313-2358. https://doi.org/10.1093/rfs/hhx009

[17] Fracassi, C. (2017) Corporate Finance Policies and Social Networks. Management Science, 63, 2420-2438. https://doi.org/10.1287/mnsc.2016.2433

[18] Rossi, A.G., Blake, D., Timmermann, A., Tonks, I. and Wermers, R. (2018) Network Centrality and Delegated Investment Performance. Journal of Financial Economics, 128, 183-206. https://doi.org/10.1016/j.jfineco.2018.02.003

[19] Hambrick, D.C. and Mason, P.A. (1984) Upper Echelons: The Organization as a Reflection of Its Top Managers. Academy of Management Review, 9, 193-206. https://doi.org/10.5465/amr.1984.4277628

[20] Granovetter, M. (1985) Economic Action and Social Structure: The Problem of Embeddedness. American Journal of Sociology, 91, 481-510.

https://doi.org/10.1086/228311 
[21] Wellman, B. and Berkowitz, S.D. (1988) Social Structures: A Network Approach. Cambridge University Press, New York.

[22] Brass, D.J., Galaskiewicz, J., Greve, H.R. and Tsai, W. (2004) Taking Stock of Networks and Organizations: A Multilevel Perspective. Academy of Management Journal, 47, 795-817. https://doi.org/10.5465/20159624

[23] Peng, M.W. and Luo, Y. (2000) Managerial Ties and Firm Performance in a Transition Economy: The Nature of a Micro-Macro Link. Academy of Management Journal, 43, 486-501. https://doi.org/10.2307/1556406

[24] Hochberg, Y.V., Ljungqvist, A. and Lu, Y. (2007) Whom You Know Matters: Venture Capital Networks and Investment Performance. Journal of Finance, 62, 251-301. https://doi.org/10.1111/j.1540-6261.2007.01207.x

[25] Chen, Y. and Xie, D. (2011) Network Location, Independent Director Governance and Investment Efficiency. Management World, 7, 113-127.

[26] Chen, Y. (2014) Directors' Social Networks and Firm Efficiency: A Structural Embeddedness Perspective. China Journal of Accounting Studies, 2, 53-73. https://doi.org/10.1080/21697221.2014.887415

[27] Bouwman, C.H.S. (2011) Corporate Governance Propagation through Overlapping Directors. Review of Financial Studies, 24, 2358-2394.

https://doi.org/10.1093/rfs/hhr034

[28] Helmers, C., Patnam, M. and Rau, P.R. (2017) Do Board Interlocks Increase Innovation? Evidence from a Corporate Governance Reform in India. Journal of Banking and Finance, 80, 51-70. https://doi.org/10.1016/j.jbankfin.2017.04.001

[29] Oh, W.Y. and Barker, V.L. (2018) Not All Ties Are Equal: CEO Outside Directorships and Strategic Imitation in R\&D Investment. Journal of Management, 44, 1312-1337. https://doi.org/10.1177/0149206315614371

[30] Faleye, O., Kovacs, T. and Venkateswaran, A. (2014) Do Better-Connected CEOs Innovate More? Journal of Financial and Quantitative Analysis, 49, 1201-1225. https://doi.org/10.1017/S0022109014000714

[31] Adams, R.B. and Ferreira, D.A. (2007) Theory of Friendly Boards. Journal of Finance, 62, 217-250. https://doi.org/10.1111/j.1540-6261.2007.01206.x

[32] Kang, J.K., Liu, W.L., Low, A. and Zhang, L. (2018) Friendly Boards and Innovation. Journal of Empirical Finance, 45, 1-25.

https://doi.org/10.1016/j.jempfin.2017.09.007

[33] Liu, S., Lin, Z., Sun, F. and Chen, H. (2015) The Impact of Financing Constraints and Agency Costs on the Corporate R\&D Investment in China. Accounting Research, 11, 62-68+97.

[34] Holmstrom, B. (1989) Agency Costs and Innovation. Journal of Economic Behavior and Organization, 12, 305-327. https://doi.org/10.1016/0167-2681(89)90025-5

[35] Jensen, M.C. and Meckling, W.H. (1976) Theory of the Firm: Managerial Behavior, Agency Costs and Ownership Structure. Journal of Financial Economics, 3, 305-360. https://doi.org/10.1016/0304-405X(76)90026-X

[36] Zenger, T.R. (1994) Explaining Organizational Diseconomies of Scale in R\&D: Agency Problems and the Allocation of Engineering Talent, Ideas, and Effort by Firm Size. Management Science, 40, 708-729. https://doi.org/10.1287/mnsc.40.6.708

[37] Hall, B.H. (2002) The Financing of Research and Development. Oxford Review of Economic Policy, 18, 35-51. https://doi.org/10.1093/oxrep/18.1.35

[38] Francis, J. and Smith, A. (1995) Agency Costs and Innovation Some Empirical Evidence. Journal of Accounting and Economics, 19, 383-409. 
https://doi.org/10.1016/0165-4101(94)00389-M

[39] Chen, Y. (2012) The Network Attributes of Independent Directors and Firm's Agency Costs. Economic Management Journal, 34, 67-76.

[40] Himmelberg, C.P. and Petersen, B.C. (1994) R\&D and Internal Finance: A Panel Study of Small Firms in High-Tech Industries. Review of Economics and Statistics, 76, 38-51. https://doi.org/10.2307/2109824

[41] Brown, J.R., Fazzari, S.M. and Petersen, B.C. (2009) Financing Innovation and Growth: Cash Flow, External Equity, and the 1990s R\&D Boom. Journal of Finance, 64, 151-185. https://doi.org/10.1111/j.1540-6261.2008.01431.x

[42] Hao, G.Q. and Li, K. (2016) The Bright Side of Discretionary Accruals: Evidence from Finance and Innovation. European Financial Management, 22, 540-575. https://doi.org/10.1111/eufm.12068

[43] Guariglia, A. and Liu, P. (2014) To What Extent do Financing Constraints Affect Chinese Firms' Innovation Activities? International Review of Financial Analysis, 36, 223-240. https://doi.org/10.1016/j.irfa.2014.01.005

[44] Zhang, X., Liu, B., Wang, T. and Li, C. (2017) Credit Rent-Seeking, Financing Constraint and Corporate Innovation, Economic Research Journal, 5, 161-174.

[45] Hsu, P.H., Tian, X. and Xu, Y. (2014) Financial Development and Innovation: CrossCountry Evidence. Journal of Financial Economics, 112, 116-135.

https://doi.org/10.1016/j.jfineco.2013.12.002

[46] Howell, S.T. (2017) Financing Innovation: Evidence from R\&D Grants. American Economic Review, 107, 1136-1164. https://doi.org/10.1257/aer.20150808

[47] Xu, N. and Cao, C. (2016) Independent Directors' Network and Chinese Listed Firms' Cash Holding. Nankai Economic Studies, 6, 106-125.

[48] Chuluun, T., Prevost, A. and Upadhyay, A. (2017) Firm Network Structure and Innovation. Journal of Corporate Finance, 44, 193-214. https://doi.org/10.1016/j.jcorpfin.2017.03.009

[49] Fang, V.W., Tian, X. and Tice, S. (2014) Does Stock Liquidity Enhance or Impede Firm Innovation? Journal of Finance, 69, 2085-2125. https://doi.org/10.1111/jofi.12187

[50] Pakes, A. (1985) On Patents, R\&D, and the Stock Market Rate of Return. Journal of Political Economy, 93, 390-409. https://doi.org/10.1086/261305

[51] Mudambi, R. and Swift, T. (2014) Knowing When to Leap: Transitioning between Exploitative and Explorative R\&D. Strategic Management Journal, 35, 126-145. https://doi.org/10.1002/smj.2097

[52] Chemmanur, T.J. and Tian, X. (2018) Do Antitakeover Provisions Spur Corporate Innovation? A Regression Discontinuity Analysis. Journal of Financial and Quantitative Analysis, 53, 1163-1194. https://doi.org/10.1017/S0022109018000029

[53] Li, J., Xia, J. and Zajac, E.J. (2018) On the Duality of Political and Economic Stakeholder Influence on Firm Innovation Performance: Theory and Evidence from Chinese Firms. Strategic Management Journal, 39, 193-216. https://doi.org/10.1002/smj.2697

[54] Cai, J., Walkling, R.A. and Yang, K. (2016) The Price of Street Friends: Social Networks, Informed Trading, and Shareholder Costs. Journal of Financial and Quantitative Analysis, 51, 801-837. https://doi.org/10.1017/S0022109016000399

[55] Ang, J.S., Cole, R.A. and Lin, J.W. (2000) Agency Costs and Ownership Structure. Journal of Finance, 55, 81-106. https://doi.org/10.1111/0022-1082.00201

[56] Singh, M. and Davidson, W.N.III. (2003) Agency Costs, Ownership Structure and 
Corporate Governance Mechanisms. Journal of Banking and Finance, 27, 793-816. https://doi.org/10.1016/S0378-4266(01)00260-6

[57] Li, S. (2007) Ownership, Agency Cost and Agency Efficiency. Economic Research Journal, 1, 102-113.

[58] Xu, S. and Xu, L. (2015) Cash Dividend Policy, Agency Cost and Corporate Performance. Journal of Management Science, 28, 96-110.

[59] Hadlock, C.J. and Pierce, J.R. (2010) New Evidence on Measuring Financial Constraints: Moving Beyond the KZ Index. Review of Financial Studies, 23, 1909-1940. https://doi.org/10.1093/rfs/hhq009

[60] Kaplan, S.N. and Zingales, L. (1997) Do Investment-Cash Flow Sensitivities Provide Useful Measures of Financing Constraints? Quarterly Journal of Economics, 112, 169-215. https://doi.org/10.1162/003355397555163

[61] Whited, T.M. and Wu, G. (2006) Financial Constraints Risk. Review of Financial Studies, 19, 531-559. https://doi.org/10.1093/rfs/hhj012

[62] Ju, X., Lu, D. and Yu, Y. (2013) Financing Constraints, Working Capital Management and the Persistence of Firm Innovation. Economic Research Journal, 1, 4-16.

[63] Yang, D., Chen, H. and Liu, Q. (2017) Media Pressure and Corporate Innovation. Economic Research Journal, 8, 125-139.

[64] Balsmeier, B., Fleming, L. and Manso, G. (2017) Independent Boards and Innovation. Journal of Financial Economics, 123, 536-557.

https://doi.org/10.1016/j.jfineco.2016.12.005

[65] Bound, J., Jaeger, D.A. and Baker, R.M. (1995) Problems with Instrumental Variables Estimation When the Correlation between the Instruments and the Endogenous Explanatory Variable Is Weak. Journal of the American Statistical Association, 90, 443-450. https://doi.org/10.1080/01621459.1995.10476536

[66] Angrist, J.D., Imbens, G.W. and Rubin, D.B. (1996) Identification of Causal Effects Using Instrumental Variables. Journal of the American Statistical Association, 91, 444-455. https://doi.org/10.1080/01621459.1996.10476902

[67] Preacher, K.J. and Hayes, A.F. (2008) Asymptotic and Resampling Strategies for Assessing and Comparing Indirect Effects in Multiple Mediator Models. Behavior Research Methods, 40, 879-891. https://doi.org/10.3758/BRM.40.3.879

[68] Zhao, X., Lynch, J.G. and Chen, Q. (2010) Reconsidering Baron and Kenny: Myths and Truths about Mediation Analysis. Journal of Consumer Research, 37, 197-206. https://doi.org/10.1086/651257

[69] Fich, E.M. and Shivdasani, A. (2006) Are Busy Boards Effective Monitors? Journal of Finance, 61, 689-724. https://doi.org/10.1111/j.1540-6261.2006.00852.x

[70] Lind, J.T. and Mehlum, H. (2010) With or without U? the Appropriate Test for A U-Shaped Relationship. Oxford Bulletin of Economics and Statistics, 72, 109-118. https://doi.org/10.1111/j.1468-0084.2009.00569.x

[71] Haans, R., Pieters, C. and He, Z. (2016) Thinking about U: Theorizing and Testing U- and Inverted U-Shaped Relationships in Strategy Research. Strategic Management Journal, 37, 1177-1195. https://doi.org/10.1002/smj.2399

[72] Dalton, D.R., Hitt, M.A., Certo, S.T. and Dalton, C.M. (2007) The Fundamental Agency Problem and Its Mitigation: Independence, Equity, and the Market for Corporate Control. Academy of Management Annals, 1, 1-64. https://doi.org/10.5465/078559806

[73] Misangyi, V.F. and Acharya, A.G. (2014) Substitutes or Complements? A Configurational Examination of Corporate Governance Mechanisms. Academy of Man- 
agement Journal, 57, 1681-1705. https://doi.org/10.5465/amj.2012.0728

[74] Yu, C. and He, L. (2019) How Does Director of Board Network Change the Innovative Behavior of Enterprises? China Journal of Economics, 6, 146-186. 